\title{
PENGARUH INTERVENSI NONFARMAKOLOGI DAN \\ FARMAKOLOGI TERHADAP PENURUNAN INTENSITAS NYERI PADA PASIEN PENYAKIT JANTUNG KORONER DI RUANG ICCU RSU KOTA LANGSA TAHUN 2012
}

\author{
Sunarsih Rahayu, Amrin \\ Kementerian Kesehatan Politeknik Kesehatan Surakarta Jurusan Keperawatan, RSU Kota Langsa
}

\begin{abstract}
Intervention of Nonpharmacological And Pharmacological, Coronary Heart Disease, Pain Intensity. Chest pain in the cardiovascular system is one of the main complaints which often complained patients to ask for medical help. The pain is different from one individual to another based on the pain threshold and tolerance release of endorphins enkefalin which incurred hifofisis into the circulation. The chest pain which felt by the patients tend to require more urgent attention than the other symptoms. Objectives of the study was to determine the intervention effect of pharmacologi and nonpharmacologi to pain intensity decrease in coronary heart disease patients. This type of research was experimental, research design using quasi experiment. Sampling using total of sampling method. Analysis of data used was $t$ dependent test. Results was show that there was a significant effect between intensity of pain before intervention to the intensity of pain after intervention. Conclusion, Intervention of nonpharmacologi and pharmacologi provide a positive and significant effect on pain intensity decrease.
\end{abstract}

Key Words : Intervention of nonpharmacological and pharmacological, coronary heart disease, pain intensity.

\begin{abstract}
Abstrak : Intervensi Nonfarmakologi dan Farmakologi, Penyakit Jantung Koroner, Intensitas Nyeri. Nyeri dada pada gangguan sistem kardiovaskuler merupakan salah satu keluhan utama yang sering dirasakan pasien untuk meminta pertolongan. Rasa nyeri berbeda dari satu individu ke individu yang lain berdasarkan ambang nyeri dan toleransi pengeluaran endorfin enkefalin yang dikeluarkan hifofisis ke sirkulasi. Nyeri dada yang dirasakan oleh pasien cenderung memerlukan perhatian yang lebih mendesak daripada gejala lainnya. Penelitian ini bertujuan untuk mengetahui pengaruh intervensi nonfarmakologi dan farmakologi terhadap penurunan intensitas nyeri pada pasien penyakit jantung koroner. Desain penelitian ini menggunakan eksperimen semu (quasi experiment designs).Sampel yang digunakan pada penelitian ini adalah total sampling. Penelitian dilakukan pada bulan Februari 2012 di Ruang ICCU RSU Kota Langsa. Analisa data dengan menggunakan uji t dependen. Hasil penelitian menunjukkan ada pengaruh yang signifikan antara intensitas nyeri sebelum diberikan intervensi dengan intensitas nyeri setelah diberikan intervensi.

Kesimpulan pada peneltian ini adalah bahwa intervensi nyeri nonfarmakologi dan farmakologi memberikan pengaruh yang positif dan signifikan terhadap penurunan intensitas nyeri.
\end{abstract}


Kata Kunci : Intervensi Nonfarmakologi dan Farmakologi, Penyakit Jantung Koroner, Intensitas Nyeri.

\section{PENDAHULUAN}

Nyeri dalam tingkatan tertentu pasti pernah dialami oleh setiap individu. Nyeri merupakan alasan yang paling umum seseorang untuk mencari perawatan kesehatan (Potter dan Perry, 2005). Nyeri adalah pengalaman sensori dan emosional yang tidak menyenangkan yang muncul akibat kerusakan jaringan yang aktual atau potensial. Nyeri merupakan sesuatu yang sangat kompleks dan banyak faktor yang mempengaruhi pengalaman nyeri seseorang. Perawat mempertimbangkan semua faktor yang mempengaruhi rasa nyeri pada pasien. Hal ini sangat penting dalam upaya untuk memastikan bahwa perawat menggunakan pendekatan yang holistik dalam pengkajian dan perawatan pasien yang mengalami nyeri, (Muttaqin A, 2008). Nyeri dada pada gangguan sistem kardiovaskuler merupakan salah satu keluhan utama yang sering terjadi pasien untuk meminta pertolongan kesehatan. Rasa nyeri berbeda dari satu individu ke individu yang lain berdasarkan ambang nyeri dan toleransi pengeluaran endorfin enkefalin yang dikeluarkan hifofisis ke sirkulasi. Nyeri dada yang dirasakan oleh pasien cenderung memerlukan perhatian yang lebih mendesak daripada gejala-gejala lainnya (Muttaqin A, 2009). Perawat harus mempelajari cara verbal dan non verbal pasien dalam mengkomunikasikan rasa ketidaknyamanan. Meringis, menekuk salah satu bagian tubuh dan postur tubuh yang tidak lazim merupakan contoh ekspresi nyeri secara non verbal. Pasien yang tidak mampu berkomunikasi efektif sering kali membutuhkan perhatian khusus selama pengkajian.

Penyakit Jantung Koroner (PJK) adalah penyakit jantung yang disebabkan oleh adaanya penyempitan arteri koroner. Mereka yang terkena penyakit ini merasa tertekan saat berjalan, lebih-lebih jika mendaki atau segera setelah makan, oleh suatu sensasi yang bersifat nyeri dan tak terfokus, yang terjadi di dada dan bisa berakibat fatal bila berlangsung terusmenerus atau intensitasnya meningkat (Huon H. Gray, et all, 2002). Saat pasien menderita nyeri, maka pasien dapat mengalami gangguan status fungsi yang serius. Mobilisasi, aktivitas perawatan diri, sosialisasi di lingkungan luar rumah, dan toleransi aktivitas dapat mengalami penurunan. Hal ini dapat menurunkan produktivitas seseorang apalagi angka kejadian PJK semakin tahun semakin meningkat karena pergeseran pola hidup masyarakat.

Di Amerika Serikat, hampir 80 juta orang atau 1 dari 3 orang dewasa, memiliki 1 atau lebih jenis penyakit kardiovaskuler (cardiovaskuler disease/CVD). Menurut American Heart Association (AHA), hampir 2.400 orang Amerika meninggal karena CVD. Setiap hari, rata-rata 1 kematian setiap 37 detik. Pada tahun 2004 pasien angina tidak stabil terhitung sekitar 89.000 pasien (Hull and Wix, 2008). Di Indonesia kasus PJK semakin sering ditemukan karena pesatnya perubahan gaya hidup. Meskipun belum ada data epidemiologis yang pasti, angka morbiditas dan mortalitasnya, cenderung meningkat. Berdasarkan laporan hasil riset 
kesehatan dasar (RISKESDA) Indonesia tahun 2007 yang diterbitkan oleh Departemen Kesehatan Republik Indonesia tahun 2008 di Jakarta, prevalensi nasional penyakit jantung adalah 7,2 \% (berdasarkan diagnosis tenaga kesehatan dan gejala), sedangkan proporsi angka kematian di perkotaan pada kelompok umur 45-54 tahun penyakit jantung menduduki urutan ke tiga $(8,7 \%)$ sebagai penyebab kematian (Wirawan, 2011). Di Intensif Coronary Care Unit (ICCU) RSUD Kota Langsa jumlah pasien yang dirawat selama periode bulan Januari - Desember 2011 terdapat 103 orang penderita PJK dengan keluhan utama nyeri dada.

Strategi penatalaksanaan nyeri terdiri atas intervensi yang bersifat independen atau nonfarmakologi dan intervensi kolaboratif atau pendekatan farmakologi. Pendekatan ini diseleksi berdasarkan kebutuhan dan tujuan pasien secara individu. Analgesik yang tepat digunakan sesuai yang diresepkan dan jangan dianggap hanya sebagai upaya terakhir ketika tindakan pereda nyeri lainnya tidak berhasil. Semua intervensi akan sangat berhasil bila dilakukan sebelum nyeri menjadi lebih parah, dan keberhasilan terbesar sering dicapai jika beberapa intervensi diterapkan secara simultan. Faktor yang memperberat dan mengurangi nyeri lebih penting daripada kualitas nyeri dalam memberikan data mengenai mekanisme nyeri. Nyeri yang ditimbulkan oleh aktivitas dan mereda setelah beberapa menit istirahat mengisyaratkan iskemia misalnya, angina pektoris pada penyakit jantung koroner (Anderson P dan Lorraine W, 2005).

\section{METODE PENELITIAN}

Rancangan penelitian sangat erat hubungannya dengan tujuan penelitian. Dalam penelitian ini karena tujuan penelitiannya adalah ingin mengetahui pengaruh intervensi nonfarmakologi dan farmakologi terhadap penurunan intensitas nyeri pada pasien penyakit jantung koroner , maka rancangan penelitian yang digunakan adalah eksperimen semu (quasi experiment designs).

Penelitian dilakukan pada bulan Februari-Maret 2012 di Ruang ICCU Rumah Sakit Umum Kota Langsa. Sampel yang digunakan pada penelitian ini adalah total sampling. Kriteria inklusi pada penelitian ini adalah, pasien PJK yang dirawat di ruang ICCU dengan kesadaran penuh dan dapat berkomunikasi dengan baik, bersedia menjadi responden penelitian dengan mengisi lembar persetujuan (informed consent).

Analisis data dilakukan untuk mengetahui pengaruh intervensi nonfarmakologi dan farmakologi terhadap penurunan intensitas nyeri pada pasien penyakit jantung koroner, maka digunakan uji $t$ dependen.

\section{HASIL PENELITIAN}

Rata-rata intensitas nyeri sebelum intervensi adalah 4.47 dengan standard deviasi 1.457, sedangkan rata-rata intensitas nyeri sesudah intervensi adalah 2.47 dengan standard deviasi 1.506. intensitas nyeri sebelum intervensi pada rentang nilai minimum 2 dan nilai maksimum 7 , sedangkan intensitas nyeri sesudah intervensi pada rentang nilai minimum 0 dan nilai maksimum 5 . 
Rata-rata pengukuran intensitas nyeri sebelum dan sesudah intervensi adalah 2.000 (95\% CI : 1.581-2.419) dengan standard deviasi 0.756. Ada pengaruh yang yang signifikan antara intensitas nyeri sebelum diberikan intervensi dengan intensitas nyeri setelah diberikan intervensi, dengan nilai $\mathrm{p} 0.000$.

\section{PEMBAHASAN}

Nyeri dada pada sistem kardiovaskular merupakan salah satu keluhan utama yang sering dikeluhkan pasien untuk meminta pertolongan kesehatan. Rasa nyeri berbeda dari satu individu dengan individu lainnya berdasarkan ambang nyeri dan toleransi pengeluaran endorphin enkefalin yang dikeluarkan hipofisis ke sirkulasi. Nyeri dada yang dirasakan klien cenderung memerlukan perhatian yang lebih mendesak daripada gejala lainnya (Muttaqin A, 2009). Teori ini menjelaskan mengapa intensitas nyeri berbeda antara satu individu dengan individu lainnya. Berdasarkan hasil penelitian, didapatkan bahwa intensitas nyeri sebelum intervensi pada rentang nilai minimum 2 dan nilai maksimum 7.

Obat antiangina bertujuan untuk meningkatkan aliran darah, baik dengan menambah suplai oksigen maupun dengan mengurangi kebutuhan miokardium akan oksigen. Efek utama dari nitrat adalah menurunkan tonus vena yang menurunkan beban kerja jantung. Penghambat beta dan penghambat kalsium mengurangi beban kerja jantung serta mengurangi kebutuhan oksigen.

Fokus perhatian pada nyeri dapat mempengaruhi persepsi nyeri. Perhatian yang meningkat dihubungkan dengan nyeri yang meningkat, sedangkan upaya pengalihan (distraksi) dihubungkan dengan respon nyeri yang menurun. Konsep ini merupakan salah satu konsep yang diterapkan perawat di berbagai terapi untuk menghilangkan nyeri seperti relaksasi, teknik imajinasi terbimbing, dan masase. Dengan memfokuskan perhatian dan konsentrasi pasien pada stimulus yang lain, maka perawat menempatkan nyeri pada kesadaran yang perifer. Biasanya hal ini menyebabkan toleransi nyeri individu meningkat, khususnya terhadap nyeri yang berlangsung hanya selama waktu dsitraksi (Muttaqin A, 2008).

Berdasarkan hasil penelitian, didapatkan bahwa intensitas nyeri sesudah intervensi pada rentang nilai minimum 0 dan nilai maksimum 5 .

Menurut Muttaqin A (2009), intervensi farmakologi bertujuan untuk meningkatkan aliran darah, baik dengan menambah suplai oksigen maupun dengan mengurangi kebutuhan miokardium akan oksigen. Sedangkan intervensi non farmakologis tujuan utamanya mencakup mencegah nyeri, mengurangi risiko penurunan curah jantung, meningkatkan kemampuan perawatan diri, mengurangi cemas, menghindari salah paham terhadap sifat dasar penyakit dan perawatan yang diberikan, mematuhi program perawatan dini, dan mencegah komplikasi.

Penurunan intensitas nyeri dapat diketahui melalui pernyataan pasien tentang penurunan nyeri dada sebelum dan sesudah intervensi, dan secara obyektif melalui tanda-tanda vital dalam batas normal, wajah rileks. Dengan demikian dapat diartikan bahwa semakin cepat dan intensif pemberian intervensi nyeri non farmakologis dan farmakologis maka 
akan semakin cepat pula penurunan intensitas nyeri pada penderita penyakit jantung koroner.

Hasil uji statistik didapatkan adanya pengaruh yang signifikan antara intensitas nyeri sebelum diberikan intervensi dengan intensitas nyeri setelah diberikan intervensi. Hasil penelitian ini sesuai dengan pendapat yang disampaikan oleh Muttaqin A (2008) yaitu, semua intervensi akan sangat berhasil bila diterapkan sebelum nyeri menjadi lebih parah dan keberhasilan terbesar sering dicapai jika beberapa intervensi diterapkan secara simultan. Hal ini juga sesuai dengan hasil penelitian yang dilakukan oleh Syahriani (2010), menyimpulkan bahwa latihan relaksasai (intervensi non farmakologis) secara signifikan dapat menurunkan nyeri.

\section{KESIMPULAN DAN SARAN}

Intensitas nyeri sebelum intervensi pada rentang nilai minimum 2 dan nilai maksimum 7 , sedangkan intensitas nyeri sesudah intervensi pada rentang nilai minimum 0 dan nilai maksimum 5.

Intervensi non farmakologis dan farmakologis memberikan pengaruh yang signifikan terhadap penurunan intensitas nyeri pada pasien penyakit jantung koroner.

Penerapan intervensi nyeri nonfarmakologi dan farmakologi di ruang ICCU sudah sangat baik, namun pihak manajemen rumah sakit hendaknya dapat memfasilitasi penerbitan standar operasional prosedur tentang penerapan intervensi tersebut, mendorong penerapan intervensi nonfarmakologi (pengaturan posisi, dukungan perilaku, teknik relaksasi, manajemen sentuhan dan distraksi) untuk menurunkaan nyeri secara lebih adekuat lagi, sehingga dapat menurunkan dosis dan lama pemakaian intervensi farmakologi, yang pada akhirnya intervensi menurunkan nyeri lebih efisien dan ekonomis.

Pasien dengan kasus penyakit jantung koroner diharapkan dapat menerapkan penggunaan intervensi nyeri, khususnya untuk intervensi nyeri nonfarmakologi (pengaturan posisi, dukungan perilaku, teknik relaksasi, manajemen sentuhan dan distraksi) sebelum mendapatkan pertolongan dari petugas kesehatan melalui pembelajaran (health education) yang diberikan oleh perawat yang merawatnya.

\section{DAFTAR RUJUKAN}

Anderson P dan Lorraine W. 2005. Patofisiologi: Konsep Klinis Proses-Proses Penyakit; alih bahasa, Brahm U. Pendit, et.all. Jakarta. EGC.

Gray H. et.all. 2002. Lecture Note Kardiologi ; alih bahasa, Azwar Agoes dan Asri Dwi Rachmawati. Jakarta. Gelora Aksara Pratama.

Muttaqin A. 2009. Buku Ajar Asuhan Keperawatan Klien dengan Gangguan Sistem Kardiovaskuler dan Hematologi. Jakarta. Salemba Medika.

Muttaqin A. 2008. buku ajar asuhan Keperawatan klien dengan gangguan sistem persyarafan. Jakarta. Salemba Medika.

Potter dan Perry. 2005. Buku ajar fundamental keperawatan konsep, proses dan praktek.; alih bahasa, Renata Komala Sari. Jakarta. EGC. 